\title{
角層細胞間脂質のバリア機能
}

\section{Skin Barrier Function of Stratum Corneum Lipids}

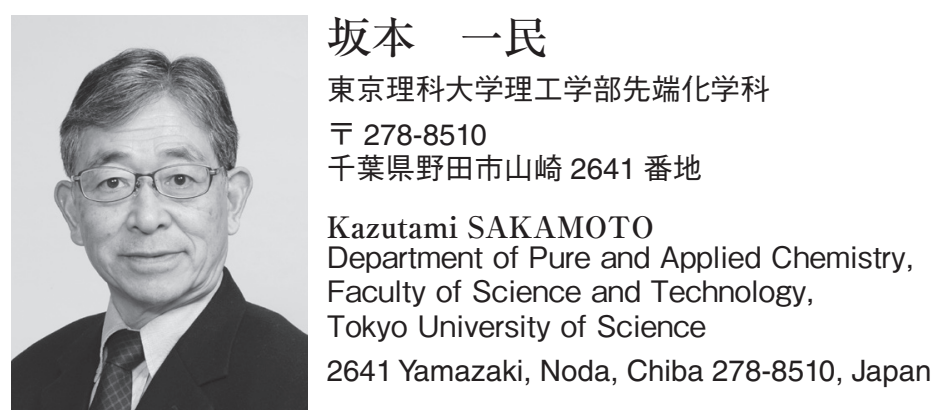

論文要旨：角層は表皮細胞の代謝物として人体の最外部に位置する厚さわずか $10 〜 30 \mu \mathrm{m}$ の薄膜層であ るが，体内からの水の蒸散を制御し外部からの物質の侵襲を防ぎ，陸棲動物としてのヒトの生存の鍵となる バリアーである。その構造は煉瓦に例えられる角層細胞と, その周りを塗り固めたモルタルに例えられるラ メラ状に配列した半固形水和ゲル状態の細胞間脂質（SCL）からなり，セラミドとコレステロールと遊離脂 肪酸を主成分とし，他の生体膜に見られない構造と機能を持つ。本稿は角層のバリア機能の中心的役割を果 たしている角層細胞間脂質 (SCL) の構造と機能について物理化学的視点から解説する。

\begin{abstract}
Stratum Corneum (SC) is the outer most thin layer of our body with merely 10 to $30 \mu \mathrm{m}$, controlling in- and outbound material trafficking as a barrier for the survival. SC consists of corneocyte, symbolized as brick, and SC intercellular lipids (SCL), symbolized as mortal. SCL exists as hydrated pseudo solid lamellar gel composed of ceramide, cholesterol and free fatty acid distinctive from any other bio-membrane. This review introduces structure and functions of SCL as a major skin barrier in view of physicochemical aspects.
\end{abstract}

Key words: stratum corneum lipids, skin barrier, pseudo solid lamellar gel, ceramide, cholesterol, free fatty acid

\section{1 はじめに}

皮膚は人体最大の臓器であり, 体内と外界の環境を隔 て人体の恒常性を維持する重要な役割を果たしている。 皮膚はその役目を果たすために様々な機能をもち, それ らを担うための複雑な構造を有している ${ }^{1)}$ 。皮膚は表皮 （約 $0.1 \sim 0.3 \mathrm{~mm}$ ) ・真皮（2３ mm）と皮下組織から成 る複合組織であるが, 実質的にバリア機能を担うのは皮 膚の最外部に位置し，わずか $10 \sim 30 \mu$ の厚さの角層で あり, 表皮細胞 (Keratinocyte) が脱核・角化した死細 胞である扁平な角層細胞 (Stratum Corneum) とその 間隙を埋めるラメラ構造を特徵とする細胞間脂質 (Stratum Corneum intercellular Lipid : SCL) から成る。角 層の構造は煉瓦（角層細胞）とモルタル（SCL）から成 る壁のような構造を持ち ${ }^{2)}$, このモデルをもとに角層の

連絡者：坂本一民

E-mail : kazusaka@rs.noda.tus.ac.jp
構造と機能に関する基礎から応用にわたる多くの研究が 知られており，モルタルに相当するSCLが皮膚のバリ ア機能の中心的役割を担っている事が明らかにされてい る。そこで本稿では経皮吸収を考えるときのメインター ゲットである SCLに焦点を当てて, 皮膚のバリア機能 を担っているラメラ構造を特徴とする細胞間脂質 (SCL) の構造と機能について考えてみたい。

角層は建物の外壁に相当し, 陸棲動物であるヒトの体 内からドライな外界への水の蒸散を抑制しつつ, 外界の 障害性物質の体内侵入を防ぐ障壁（バリア）である。壁 のモルタルにあたる角層の細胞間脂質 (SCL) は, SCL の 2 分子膜が積層した半固形水和ゲルを主構造とする複 合材料 (composite material) とも言え, 壁にひびが入っ てしまうと雨漏りが防げないようにSCLの構造とその 状態がバリア性の鍵となる。 


\section{2 特異的な生体膜である角層細胞間脂質 (SCL) の構 造的特徵}

\section{$2 \cdot 1$ リン脂質を主成分とする通常の生体膜}

赤堀やオパーリンが生命の原点として述べているよう $に^{3,4)}$, 地球上の生命の営みは水という極めて特異な性 質の液体を不可欠な媒体とし，原始地球の物質や環境の 変化の中でコアセルベートと呼ばれる外界から独立した 小胞体が生成し，やがて内外の物質代謝を制御する自律 的な自己維持と自己増殖の能力を獲得し, 細胞という生 命体に進化した。この独立生命体である細胞の存立を可 能としているのが脂質 2 分子膜の存在である。生体膜(細 胞膜）の主な構成成分は 2 本の疎水鎖を持つリン脂質, を主成分にコレステロールや，膜蛋白質など多種多様な 両親媒性物質からなり，その構造と性質は Singer と Nicolson が提唱した「流動モザイクモデル」で説明され る。すなわち, 生体膜は疎水基が液体と同様の流動性を 持ちつつ，水和した親水基を外側に向けて 2 分子膜とし て配列した，水を媒質とするリオトロピックなラメラ液 晶の状態にある。この生体膜のラメラ液晶としての柔ら かさと, 膜内外への物質の透過を抑制するバリア機能が, 独立生命体としての細胞の存在を可能としている。この ような生体膜の特性を特徴づけるのは，基本成分である リン脂質が踈水性の高い両親媒性物質で水に難溶性で, 臨界ミセル濃度が極めて低く（約 $10^{-10} \mathrm{M} ）$ 必然的に微 量の存在で自発的に会合し，その際の踈水基と親水基の 形状がバランスしていて水和した親水基が曲率を持たず に並んだラメラ液晶（L $\alpha$ ）となるためである（臨界充 填因子 $\mathrm{CPP}=\mathrm{V} / \mathrm{al}=1)$ 。多くの生体膜構成りン脂質が 2 本鎖で，しばしば不飽和あるいは分岐鎖を含むことは， 近接分子間力である van der Waals が働きにくく疎水基 を液体状態に保つのに好都合である ${ }^{5)}$ 。地上で生命体が 正常な機能を保てる温度範囲は水が液体となる $0^{\circ} \mathrm{C}$ から 約 $40^{\circ} \mathrm{C}$ と極めて狭い。これは宇宙を含めた自然界を考 えると極限に近い狭い温度範囲である。さらに，この範 囲で自己組織化して曲率の無いラメラ液晶（L $\alpha$ ；CPP =1）になる駆動力は，ミセル形成と同様に疎水基が水 との接触を嫌うことに由来する疎水性相互作用である点 に注目頂きたい。生体膜がソフトなバリアとして機能を 維持するためには曲率によるひずみエネルギーのない平 面 2 分子膜であることが必要で，ナノサイズでは曲率の ひずみが大きすぎる為，独立生命体である細胞の大きさ は $\mu \mathrm{m}$ スケールすなわち光学顕微鏡で観察可能な大きさ である ${ }^{6)}$ 。このようにソフトなリオトロピック液晶であ るリン脂質を主成分とする通常の生体膜と対比させつ つ，本総説の主題である角層細胞間脂質（SCL）の特性
を考えてみる。

\section{$2 \cdot 2$ 角層細胞間脂質 (SCL) の構成成分と構造特性}

SCL は生体膜の一種ではあるものの，構成成分的に も構造特性の点でも上記のリン脂質を主成分とする生体 膜とは大きく異なる。その主たる構成成分はセラミドと コレステロールと遊離の脂肪酸であり，モル比で $1: 1$ : 1 の割合で存在している。これら SCL 脂質の生化学的 観点からの生合成経路抢よびバリア機能に果たす役割の 詳細については内田氏の総説に譲るが，SCLの生成過 程の概略は以下の通りである。表皮細胞 (Keratinocyte) の分化後期にあたる顆粒層において SCL の親水性前駆 体であるスフィンゴミエリン，グルコシルセラミド，コ レステロールエステル,グリセロリン脂質が層板顆粒 (ラ メラボディ）として蓄積され，これら前駆体は分化の最 終段階の脱核·角化の際に角層細胞の外に放出された後, 各種酵素の作用で各 SCL 成分に変換され角層細胞の間 隙に層状の強固なバリアを形成する7)。このプロセスに 関しては定説とされてきた層板顆粒の生成と融合に至る 複雑な過程から成る Landmann モデルに加え, 最近, よりエネルギー消費の少ないプロセスとして両連続液晶 を経由する Folding モデルが提唱された ${ }^{8)}$ 。いずれの場 合も水を媒質とする細胞質ゾル（cytosol）中で, SCL 前駆体のソフトな自己組織体の状態で分散したラメラボ ディが，連続した層状（ラメラ）に構造変換し，続いて 前駆体が酵素加水分解により疎水性で高融点である SCL となり，その結果ラメラ状の構造体は SCL がバリ ア性の高いラメラ状の半固形（ラメラゲル）となる9。

この混合脂質の水和物である SCL のラメラゲルは電 子顕微鏡観察, 示唆熱分析, X 線回析, 中性子解析など 様々な測定方法を用いて調べられてきた。その結果，角 層の X 線回折による詳細な構造解析によって, SCLが 形成するラメラ構造には小角 X 線回折（SAXS）で Fig. 1 に模式的に示される短周期 $(5,7 \sim 6.0 \mathrm{~nm})$ と長周期 (13.6 nm) の 2 種類のラメラ構造が存在することが知ら れている ${ }^{10-15)}$ 。八田らは短周期ラメラには 2 分子膜の 親水基間に層の水和度に比例して変化する結合水が存在 するラメラゲルであることを示した。その詳細について は角層の水和とバリア性の観点で後述する。一方，長周 期ラメラは $\omega$ - 水酸化脂肪酸に脂肪酸がエステル結合し た長鎖のセラミドの存在に起因し，その周期は角層水分 に関わらず一定であることからラメラ層間は水和されて いない ${ }^{14,15)}$ 。

疎水基の炭化水素鎖の充填構造は広角 $\mathrm{X}$ 線回折 （WAXS）によるラメラ周期の方向と直行する面内の周 期から算出される格子定数から知ることができ，角層の SLC には Fig. 2 に示される六方晶 $(0.42 \mathrm{~nm})$ と直方晶 

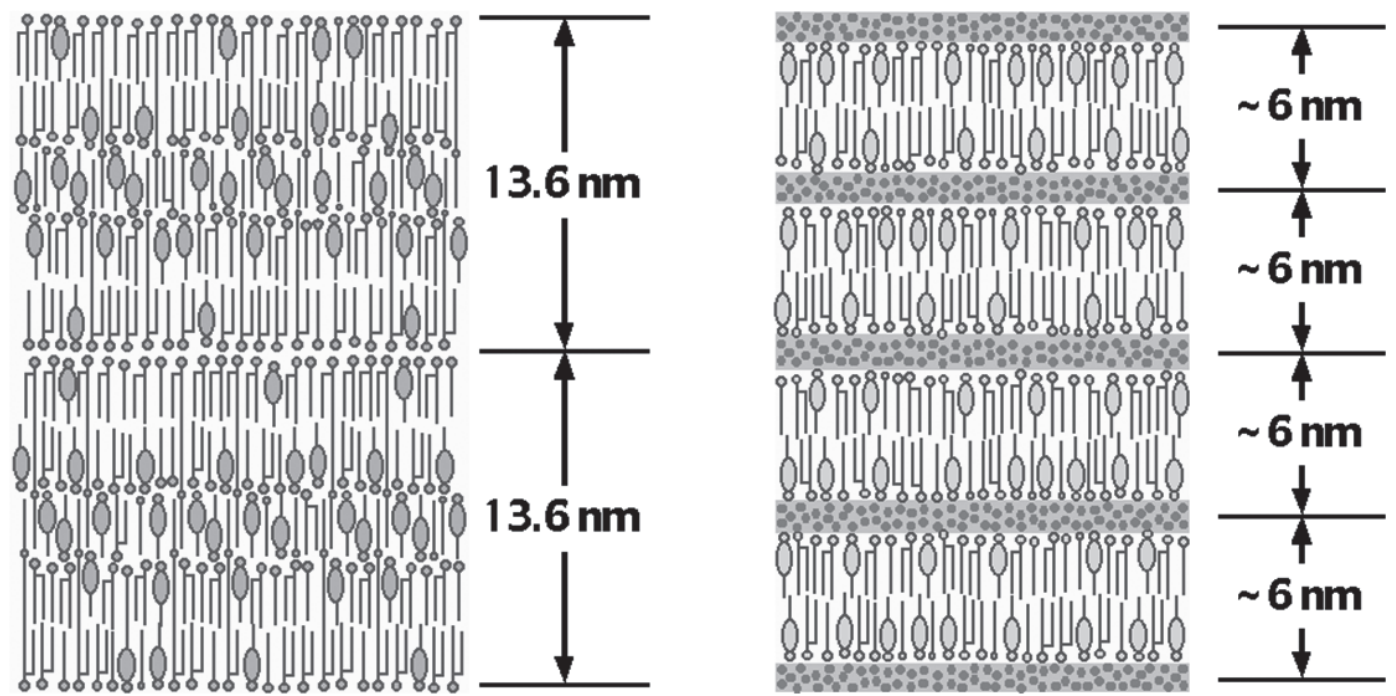

Fig. 1 角層細胞間脂質のラメラ構造の模式図 ${ }^{15)}$ 。 $\mathrm{A}$ : 長周期ラメラ構造, $\mathrm{B}$ ：短周期ラメラ構造（層間に水和水

点で表示)
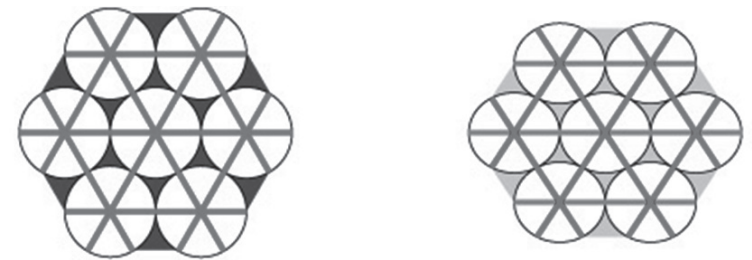

$0.42 \mathrm{~nm} \times 3$

$0.42 \mathrm{~nm} \times 2$

\section{$0.37 \mathrm{~nm} \times 1$}

\section{Hexagonal Orthorhombic}

Fig. 2 六方晶（Hexagonal）と直方晶（Orthorombic）の疎 水鎖の充填構造 ${ }^{15)}$

(0.42 nm と $0.37 \mathrm{~nm})$ が存在することが確認された ${ }^{16-18)}$ 。 さらに約 $0.46 \mathrm{~nm}$ 付近に液晶構造を示唆するブロードな ピークも観測されることから， SLCのラメラ構造には 炭化水素鎖の充填構造や状態の異なるいくつかのドメイ ンが共存すると推定される。炭化水素鎖が緻密で硬い $\beta$ - 結晶のパッキングをしていると考えられる直方晶の ピーク $(0.37 \mathrm{~nm})$ は昇温により $40^{\circ} \mathrm{C}$ 付近で消失し，そ の冷却で経皮吸収性が増加（バリア性の低下）する事が 知られているが, 一方で温度上昇による液晶ドメインの 増加がみられ，この秩序性の低いドメインがバリア機能 に関与するとの見方もあり，X 線回折による構造解析のみ でSCL の構造と機能を議論することは困難である ${ }^{14,19)} 。$

\section{3 角層細胞間脂質 (SCL) の組成とバリア性}

アトピー性皮膚炎は様々な原因に由来するが, 角層の バリア機能低下はその重要な要因のひとつであり, SCL
の主成分であるセラミドの組成変化と関連することが報 告されている。内田らはアトピー患者のセラミド関連成 分の分析からセラミドの代謝関連成分である少量のス フィンゴ脂質の組成変化を見出し，アトピー症状を呈す るマウスのSCLにおいても同様の現象を確認した ${ }^{20)}$ 。 そこで，このSCL中の微量成分のバリア機能低下への 影響を物理化学的見地から捉えて検討を進めるため, 正 常なマウスとアトピー性皮膚炎（AD）モデルマウスに おけるスフィンゴ脂質の内スフィンゴシン（So）とス フィンガニン $(\mathrm{Sa})$ の含有率とその比率の差異を反映 させたSCL モデル（Fig. 3）を調製した。これらを用い たリポソームに, 蛍光物質を内包させ, その膜透過性と 構造解析を行った ${ }^{21,22)}$ 。その結果 Fig. 4 に示すように いずれのリポソームも温度に依存してローダミンの漏出 が増加し, $\mathrm{AD}$ モデルリポソームのバリア性は正常モデ ルおよび対照の基本組成に比して優位に低く，アトピー 患者および $\mathrm{AD}$ モデルマウスに認められた皮膚バリア 機能の低下に対応する結果となった。しかしながら X 線回折（Fig. 5）および蛍光異方性測定（Fig. 6）による 膜の構造解析では 3 種のリポソームに差はなかった。こ こで用いた各 SCLリポソームは DSC で明確な液晶への 相転移ピークが認められず，X線回折の結果から広角領 域にて六方晶と直方晶相当の回折ピークが確認されてい ることから (Fig. 5), 各実験の範囲（25～70C）で皮膚 角層の SCL と同様の水和したラメラゲル (半固形水和 ゲル）が主要なドメインであると推定される。このため 微量のスフィンゴ脂質の組成変化による局所的な欠陥 （壁のひびのようなもの）の有無が SCLのバリア機能の 差として現れたと推定される。これはSCLが半固形水 和ゲルであるがゆえに生ずる現象で，無欠陥なら極めて 


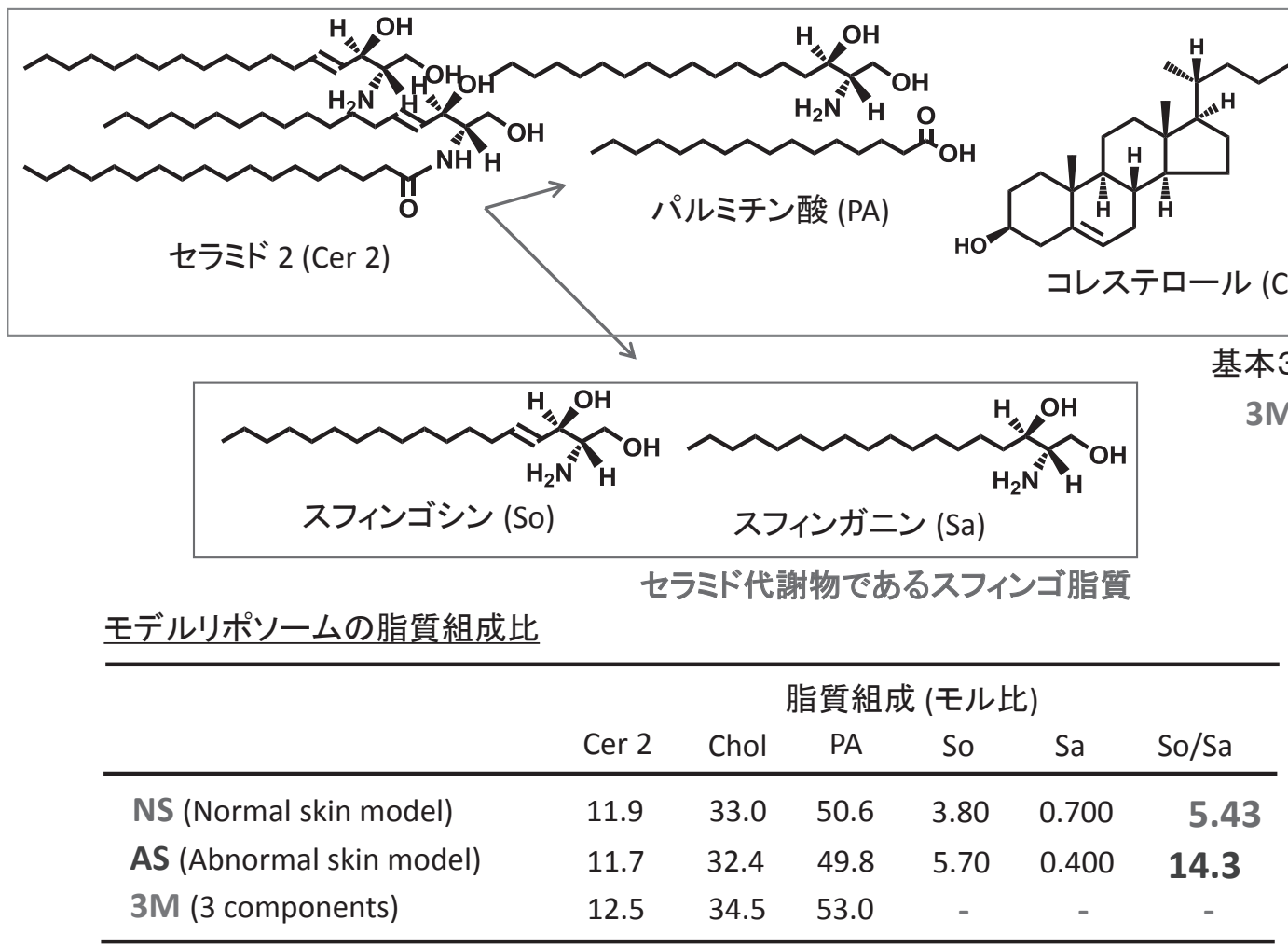

Fig. 3 モデル SCL 脂質リポソームの構造式と組成 ${ }^{21}$

\section{内包したローダミンの漏出率測定（バリア性の評価）}

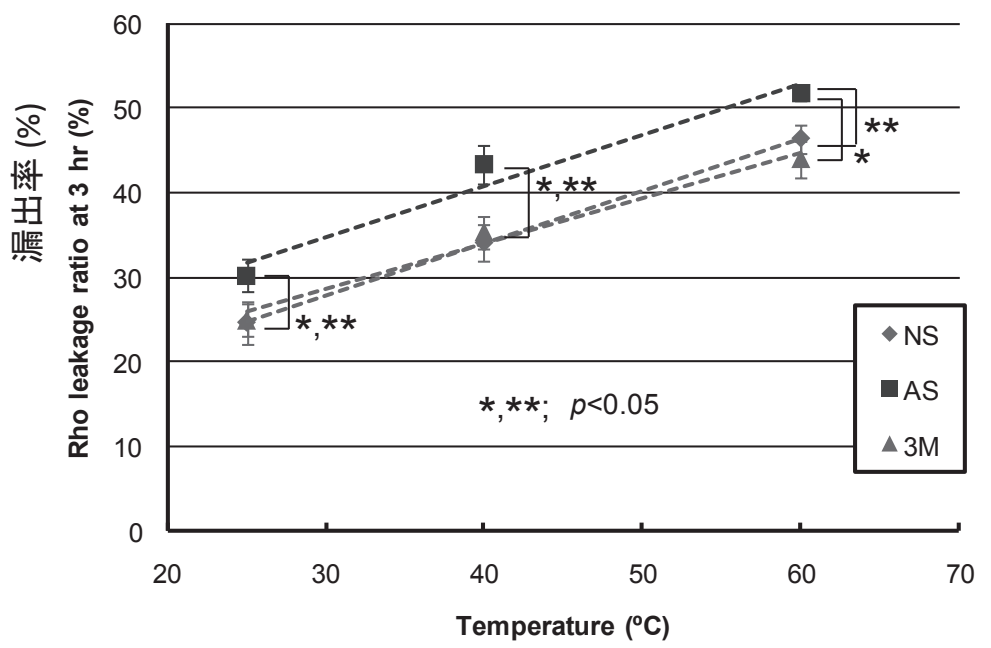

ASの漏出性はNS,3Mに比べ 有意に大きい

in vivolにおけるASとNSの

バリア性の差異と相関する

微量構成成分の差に基づく 漏出率の違いを示唆

測定温度範囲で構造変化はない

Fig. 4 各モデルリポソームからの Rho 漏出率 $(3 \text { 時間後 })^{21)}$

強固な壁も，わずかのヒビで液体が沁みとおってしまう ことに例えられる。本特集のテーマであるマイクロニー ドルを用いた経皮 DDS は，このような現象を意図的に 活用した方法ともとらえられる。

一方，通常の生体膜は液晶状態にあり膜内での拡散の 自由度を備えているので局所的欠陥は速やかに修復され る。従って液晶状態の SCL は細胞膜と同等のバリア性 を持つと想定されるので，SCL総体としては柔らかい 目地のようにラメラゲルに生じた欠陥を閉塞させバリア
性向上に寄与するのではないかと推定される。

我々はSCLの構造および膜流動性とバリア性との関 係を明らかにするために電子スピン共鳴法（ESR）に注 目し，スピンプローブとしてステアリン酸の 5 位に安定 ラジカルを持つ 5-Doxylstearic acid（5-DSA）を用いた ESR スペクトルから秩序度 $(\mathrm{S})$ を求めることにより in vivo, ex vivo, in vitroにおける SCLの構造および膜流 動性の解析法を確立し, S が皮膚のバリア性の指標であ る TEWL と良く相関することを示した $\left(\right.$ Fig. 7, 8) ${ }^{23-26)}$ 。 


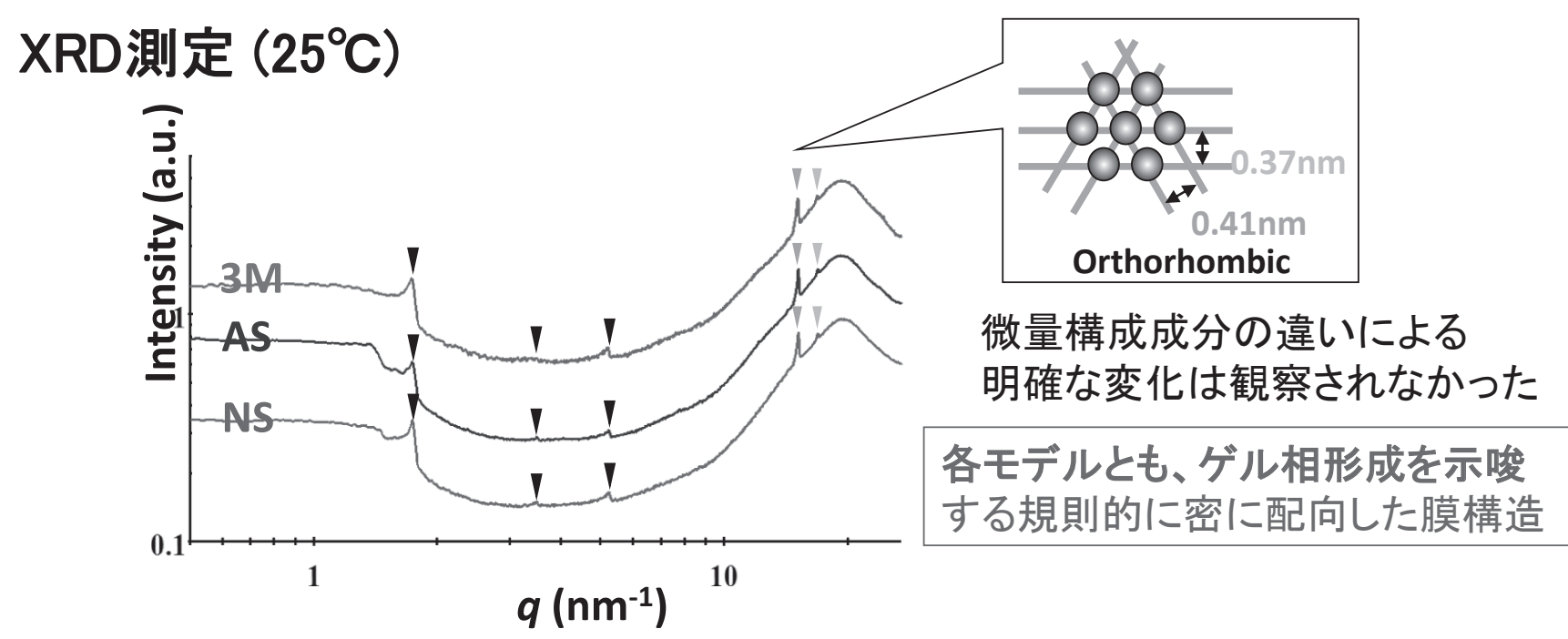

Fig. $525^{\circ} \mathrm{C}$ における各モデルリポソームの X 線回折（XRD）スペクトル ${ }^{21}$

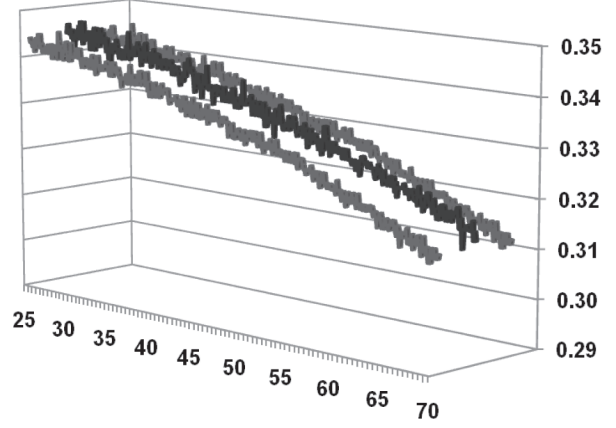

いずれの測定方法においても、液晶への 明確な相転移は観察されなかった
さらに，テープストリッピング法により角層の深さ方向 でのS 值の変化を詳細に調べた結果 SCL の規則性は落 屑の始まる比較的上層部角層まで整っている一方, テー プストリッピング後の TEWL は中層部で上昇する傾向 があり, 複層化されたSCLがバリアとして有効に機能 している事が示唆された ${ }^{27)}$ 。また種々の方法で報告さ れている角層の深さ方向での水分や NMF の含量分布や $\mathrm{pH}$ 勾配などを総合すると中層部の角層が構造的にも成 分的にも最もバランスのとれた状態にあり，角層のバリ ア機能はこれら諸因子の総合的な調和で維持されている と考えられる ${ }^{28-34) 。 ~}$

Fig. 6 蛍光異方性測定結果 昇温速度 ; $1^{\circ} \mathrm{C} / \mathrm{min}^{21}$

秩序度 (S) 5-DSAの周囲の分子の配向性と運動性を反映する 角層のバリア性 (TEWL) とよく相関する1)
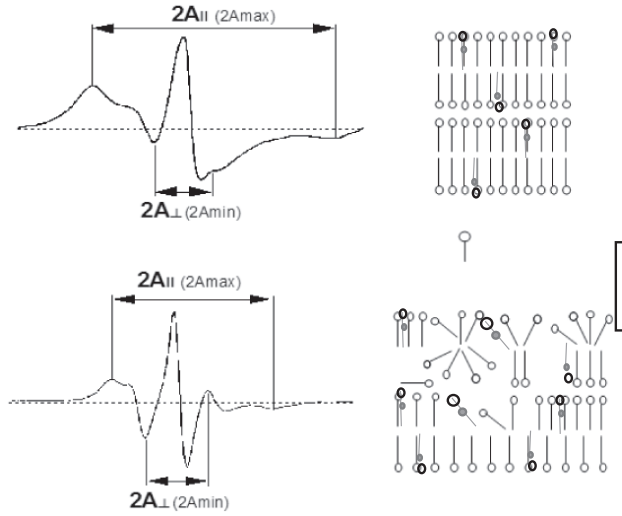

$S=\frac{A_{\|}-A_{\perp}}{A_{Z Z}-\frac{1}{2}(A X X+A Y Y)} \cdot \frac{a}{a^{\prime}} \quad a^{\prime}=\frac{A_{\|}-A_{\perp}}{3}$ $a=\frac{A_{X X}+A Y Y+A_{Z Z}}{3}$

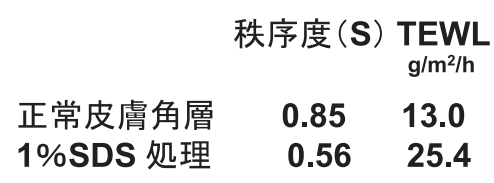

5-DSA :5-doxyl stearic acid ${ }^{\circ}$

Fig. 7 SCL モデルの物性：ESR スピンプローブ（5-DSA）法を用いた解析 ${ }^{23}$ 

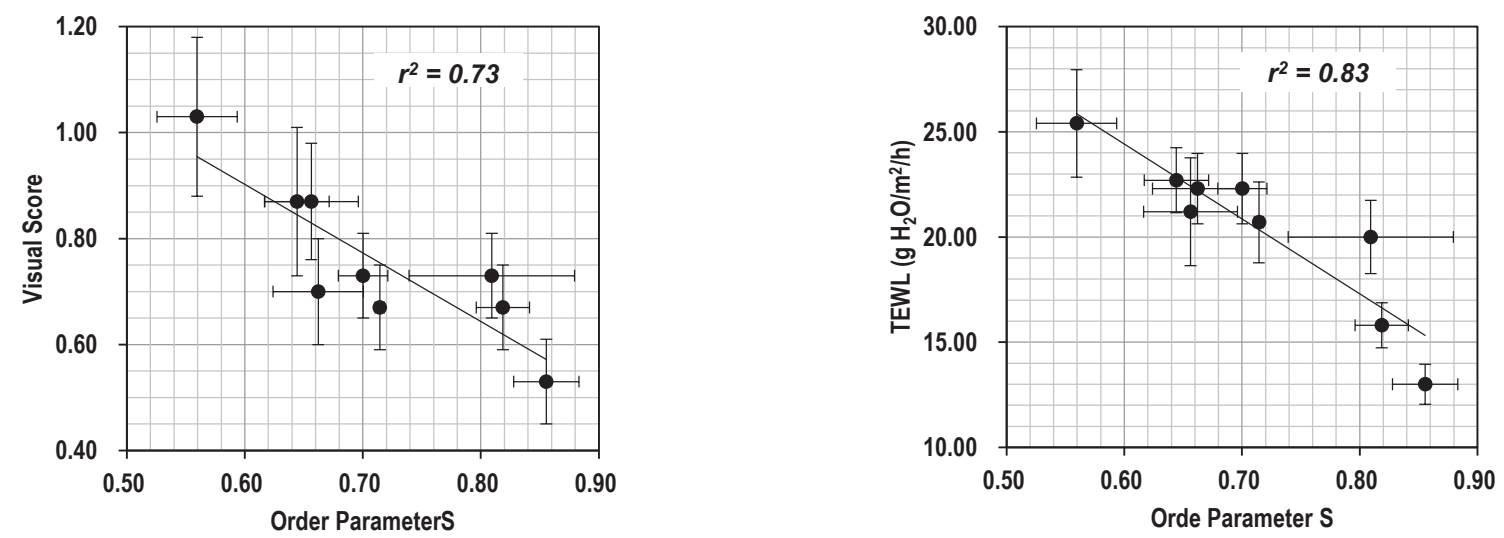

Fig. 8 界面活性剂の皮膚への影響：ESR スピンプローブ（5-DSA）法を用いた解析 ${ }^{23)}$ 。2 4 時間閉塞パッチテスト後の評価；皮 膚一次刺激性所見 vs ESR 秩序度 (S)；TEWL vs ESR 秩序度 (S)

\section{4 角層の水和による SCL の構造変化とバリア性の関係}

八田らはマウスおよびヒトの角層中の水分量と SCL のラメラ周期の関係を調べた結果，短周期ラメラの間隔 ds が水分量にほぼ比例して増加する事から, 親水基の 間隙の水和量が増大しラメラ構造が膨潤し水分子 3 個分 ほどの厚さまで達することを認めた (Fig. 9) ${ }^{15)}$ 。さらに SCL ピークの半值幅が水分 $25 \%$ 付近で最も狭く, X 線

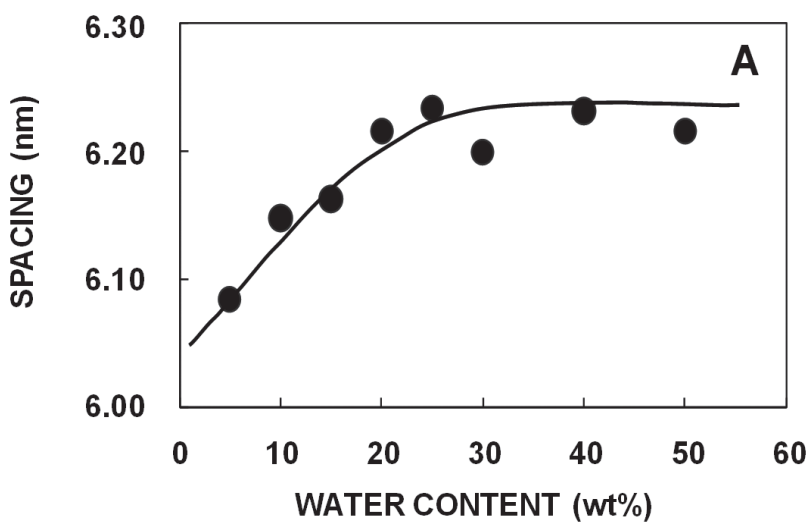

Fig. 9 七ト角層の小角 X 線回折における短周期構造の水和 量依存性 ${ }^{15)}$

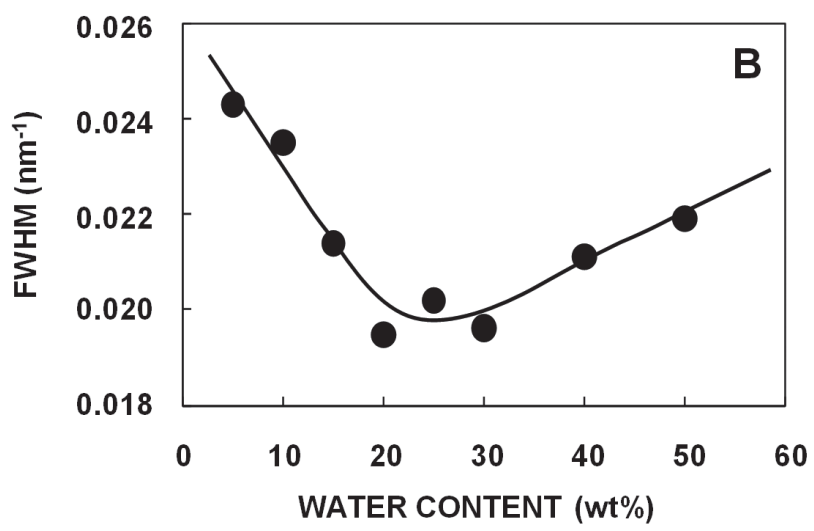

Fig. 10 ヒト角層の小角 $\mathrm{X}$ 線回折における短周期ピーク半 值幅の水和量依存性 ${ }^{15)}$
散乱ピークがシャープなほど構造の規則性が高いので, SCL が安定な半固形水和ゲルを形成する水分量と対応 することを示唆している $(\text { Fig. 10 })^{14,15,35) 。 ~}$

八田が指摘したように角層中の水分は NMFを含み保 水機能を担う角層細胞中で蓄えられており, その保持容 量を超えた水は SCL の中に水塊（Water pool）を生じ ${ }^{34)}$, 放置すると角層の剥離につながる ${ }^{36)}$ 。このように SCL 短周期構造ドメインは半固形水和ゲルとしてバリア機能 を担っており, TEWLで計測される体内水分の外部へ の透過・蒸散に関わる経路であるとともに, 外界からの 水溶性物質の侵入経路でもある。従って水溶性薬剤の経 皮 DDS を考える場合，吸収速度の制御には短周期ドメ インの水和レベルを含めたラメラ構造の摇動が効果的で あると推定される。八田らはこの観点から水とエタノー ルの混合液を角層に作用させたときの小角 $\mathrm{X}$ 線散乱像 の変化を調べ, 短周期ピーク位置に顕著な変化がなく時 間の経過とともに角層の膨潤を示唆する小角側の裾の ピークの強度の増加を認め, 親水性のエタノールは角層 細胞に侵入し, SCL ラメラの水和には影響していない と考えた $\left(\right.$ Fig. 11) ${ }^{15)}$ 。これはエタノールその他の水溶 性経皮吸収助剂が水溶性薬剂の角層細胞への分配促進に 有効であることを示唆し, 水溶性薬剤の経皮 DDSにお ける徐放性コントロールのために有効と思われる。

一般に水溶性物質は経皮吸収しにくいといわれてい る。我々はその典型的例としてアミノ酸の経皮吸収性に ついて検討した ${ }^{37)}$ 。モデルとして 5 種類のアミノ酸（LLys HCl, Gly, L-Glu Na, L-Pro, L-Thr の pH7.4 水溶液) を選び, in vivo 経皮吸収性をラジオアイソトープ標識 法で調べた。その結果, 角層剥離で 5 2 2 倍の吸収速度 の増加がみられ (Table 1, Fig. 13.14), 角層がアミノ酸 の経皮吸収に対するバリアであり SCLにおける脂質 2 分子膜の密に充填した炭化水素鎖による疎水膜がその主 体と推察される。さらに正常皮膚においてアミノ酸の経 


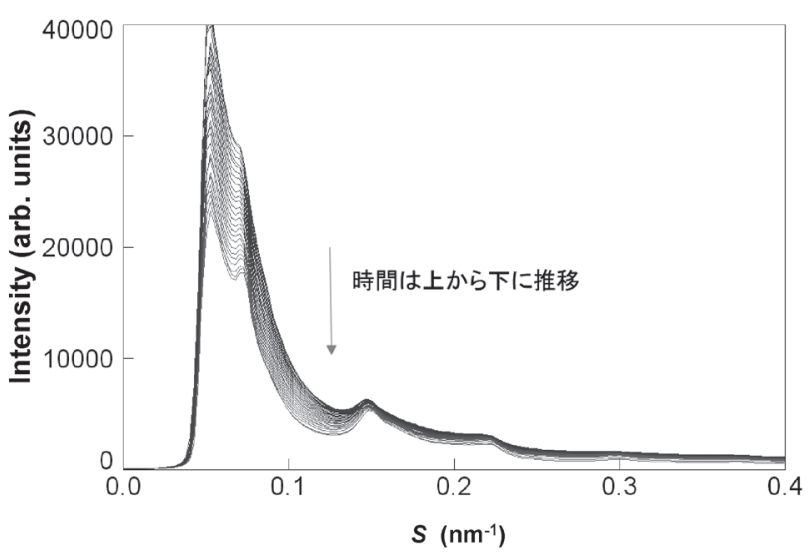

Fig. 11 ヒト角層のエタノール処理による小角 X 線散乱ピー クの経時変化 ${ }^{15)}$ 。時間は上から下に推移

皮吸収流速 $\left(\mathrm{g} / \mathrm{cm}^{2} / \mathrm{hr}\right)$ が $\log \mathrm{P}($ オクタノール/水) と負の相関にある事から，アミノ酸の親水性が関与する 「マイクロチャネル」の存在が示唆された。また, Pro の角層への吸着量が NMF の主要成分であるグリセリン やPCA ナトリウムとの共存で顕著に増大する事から (Fig. 15)，先に実用系で明らかにした相乗的保湿効果 ${ }^{38,39)}$ が検証されるとともに, 上述のように水溶性薬剤の徐放 性制御に角層細胞への分配が重要であることが確認され た。

\section{SCL の疎水性ドメインとバリア性の関係}

八田らは角層を水和させた際の SCL 長周期ドメイン の周期性は角層水分量にかかわらずほぼ一定であること から角層の水和には関与せず，脂溶性ドメインとして重

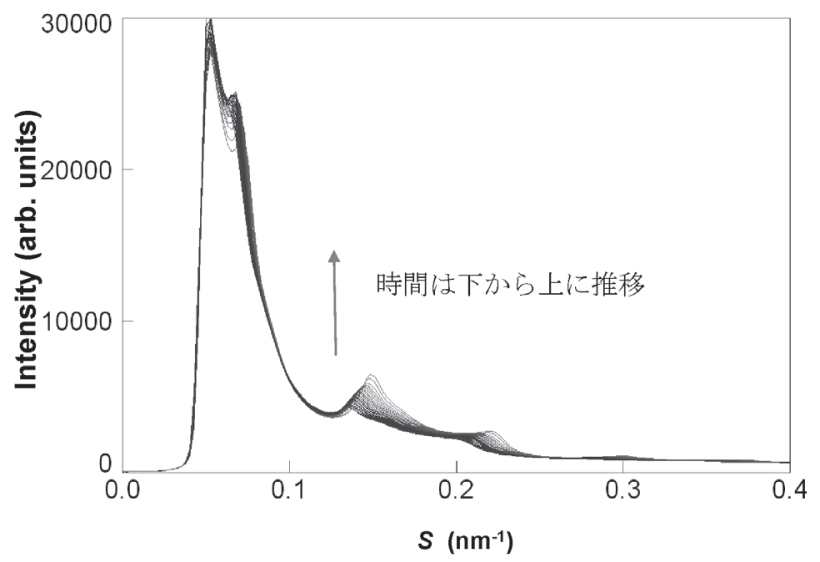

Fig. 12 ヒト角層のリモネン処理による小角 X 線散乱ピー クの経時変化 ${ }^{15)}$ 。時間は上から下に推移

要であることを示した ${ }^{14,15)}$ 。Bouwstra らは長周期ラメ ラが 3 層構造を持ち狭い中間層は乱れた構造にあり物質 透過への重要な役割を持つとの説を唱えている ${ }^{40)}$ 。八 田らは脂溶性経皮吸収助剤として知られるリモネンを角 層に作用させると長周期ラメラ構造の回折ピークが時間 とともに減少しつつ小角側に移動することから, リモネ ンが疎水鎖中心部に浸透し膨潤させていると説明した (Fig. 12) ${ }^{14,15)}$ 。これは脂溶性薬剤にとっての SCLはそ こに分配され易く，かつその中で移動しやすい環境であ り，多くの実用化された経皮 DDS 製剂が脂溶性薬剂の ものである事と符合する。

6 おわりに

角層細胞間脂質 $(\mathrm{SCL})$ のバリア機能について, 物理

Table 1 アミノ酸の経皮吸収性 ${ }^{37}$ 。 $\mathrm{MW}$ : 分子量, PI : 等電点, Flux : 透過性, LogP : 分配係数（オクタノール/水）

\begin{tabular}{|c|c|c|c|c|c|c|}
\hline & \multirow{2}{*}{ Structure } & \multirow{2}{*}{ MW } & \multirow{2}{*}{$\mathbf{P I}$} & \multicolumn{2}{|c|}{ Flux $\left(\mu g / \mathrm{cm}^{2} / \mathrm{h}\right)$} & \multirow{2}{*}{$\underset{n-o c t a n o l}{\log P} \mathbf{P}$} \\
\hline & & & & Normal skin & Stripped skin & \\
\hline $\begin{array}{l}\text { L-tysine } \\
\text { hydrochiloride }\end{array}$ & & 182.65 & 9.74 & $\begin{array}{c}0.87 \pm 0.23 \\
(n-4)\end{array}$ & $\begin{array}{c}4.15 \pm 0.36 \\
(n-4)\end{array}$ & $-4.44 \pm 0.10$ \\
\hline Glycine & & 75.07 & 5.97 & $\begin{array}{c}0.26 \pm 0.03 \\
(n=4)\end{array}$ & $\begin{array}{c}3.88 \pm 0.72 \\
(n=4)\end{array}$ & $-3.25 \pm 0.12$ \\
\hline $\begin{array}{l}\text { Mono sodium } \\
\text { L-glutamate } \\
\text { monohydrate }\end{array}$ & & 187.13 & 3.22 & $\begin{array}{c}0.53 \pm 0.06 \\
(n-4)\end{array}$ & $\begin{array}{c}4.04 \pm 0.11 \\
(n=4)\end{array}$ & $-4.19 \pm 0.08$ \\
\hline L-threonine & & 119.12 & 5.64 & $\begin{array}{c}0.22 \pm 0.02 \\
(n=4)\end{array}$ & $\begin{array}{c}4.38 \pm 0.99 \\
(n=4)\end{array}$ & $-2.91 \pm 0.10$ \\
\hline L-proline & & 115.13 & 6.30 & $\begin{array}{c}0.16 \pm 0.03 \\
(n-4)\end{array}$ & $\begin{array}{c}4.16 \pm 0.12 \\
(n-4)\end{array}$ & $-2.50 \pm 0.12$ \\
\hline
\end{tabular}




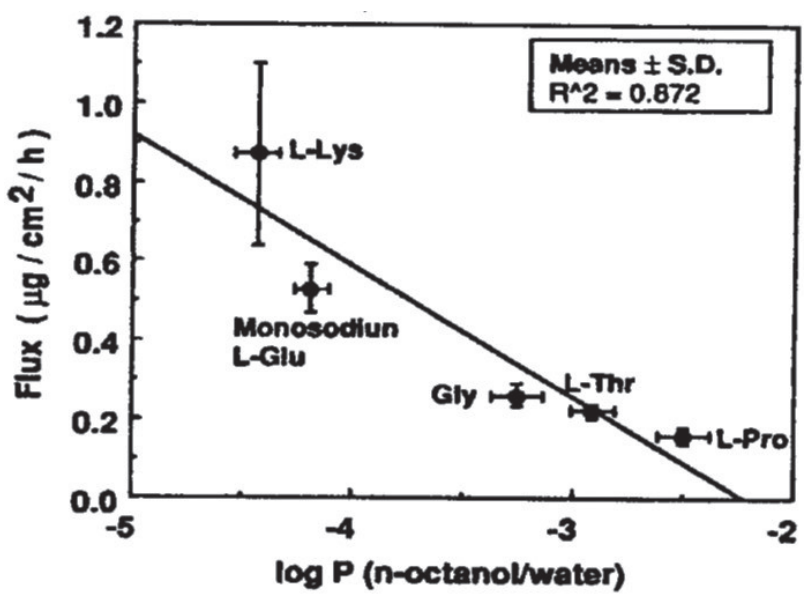

Fig. 13 アミノ酸のヒト皮膚透過性（Flux） と分配係数 $\left(\log P\right.$ ：オクタノール / 水) の関係 $(\text { 正常皮膚 })^{37}$

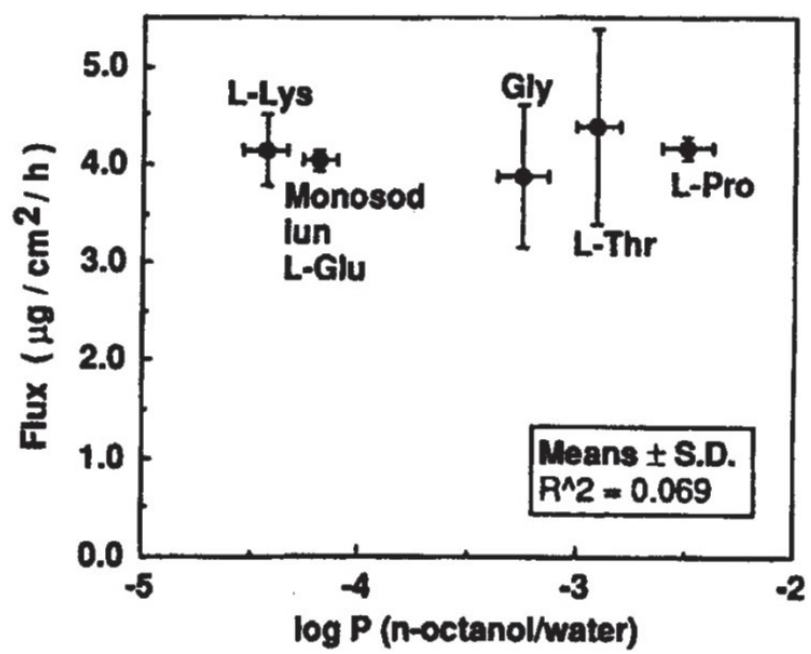

Fig. 14 アミノ酸のヒト皮膚透過性 (Flux) と分配係数 (LogP: オクタノール / 水) の関係 $(\text { 角層剥離皮膚 })^{37}$

化学的観点からその構造と機能抒よび経皮吸収製剤 （TDDS）として考虑すべき種々の要因について考えて みた。本稿では角層を Elias が提唱した「煉瓦」と「モ ルタル」から成る壁のような複合構造体を基本モデルと 考えて論を進めた。執筆を進める中で，このモデルが角 層の構造と機能を知る道しるべとして適していることを 実感しつつも，最新の知識の集積を初学者にもわかり易 く伝えるモデルとしては主役の名称を変えるか補足説明 が必要に感ずる。すなわち，「棟瓦」に例えられた「角 層細胞」はケラチン繊維を細胞骨格としNMF を含み, 落屑して乾けば平たい垢でしかないが，角層中では十分 水和してしっとりとした塊であり，しいて例えれば「ぬ れせんべい」のようなものと言える。一方，「モルタル」 に例えられた「細胞間脂質 (SCL)」は複合的な水和固 体状の脂質ラメラ構造物で，これもしいて例えればチョ コレートの粒が混じったバタークリームのようなものと 言えるかもしれない。この「ぬれせんべい」に「バター

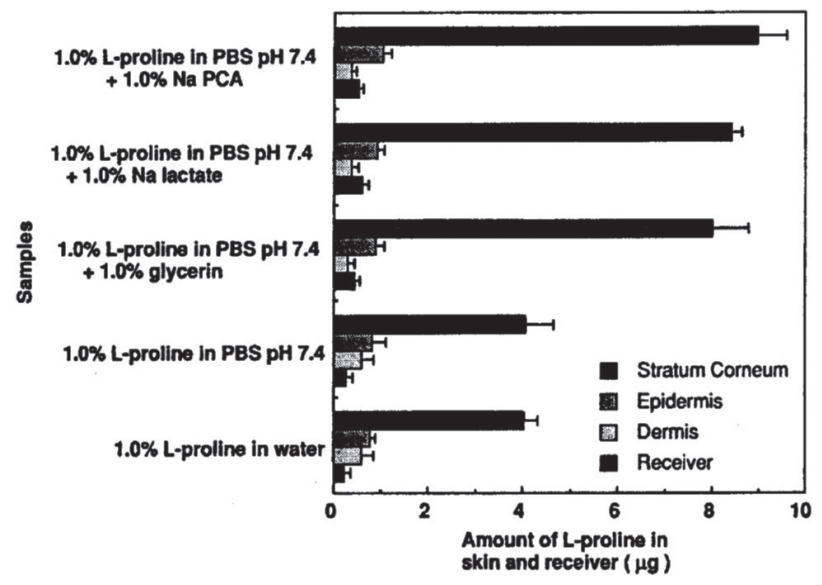

Fig. 15 L-Pro の皮膚透過性: 角層各部位への分布 $(4 \text { 時間後 })^{37)}$

クリーム」を塗りつつ重ねてできたものがうまいかどう かはさておき，これぞ角層モデルと言えるかはやってみ てのお楽しみ。圥談はさておき，極めて多成分で複雑な 角層に取り組む方法論として，vivo，vitroを問わず， 実体そのものを解析的に分解・分類そして体系化するア プローチと，それぞれのユニットおよびそれらを構成す る成分を極力単純化したモデル系を構築して, 基本構造 や機能を再構築するアプローチがある。特に後者にかん し SCL を単純なセラミド, コレステロール, 脂肪酸の 3 成分系で模倣し，本稿で紹介したような種々の知見と 照合しつつ薬剤のスクリーニングや有用性検証のツール として活用する試みが盛んにおこなわれており，その発 展と薬剤開発への貢献が期待される。

本稿では「簡便で有効な DDSとしての経皮吸収を考 える」という視点で角層細胞間脂質についてまとめたが, これらの知見は健康な肌を保つための化粧品の開発にも つながると確信している。

最後に，経皮吸収の全容を知るのに有用と思われる最 新の総説の概要を Table 2 に紹介する ${ }^{41)}$ 。多くの引用文 献をもとに経皮吸収について俯瞰的にまとめてあり，本 特集のクロスリファレンスとして活用いただければ幸い である。

\section{文 献}

1）清水宏著新しい皮膚科学 第 2 版, 第 1 章, （http:// www.derm-hokudai.jp/textbook/pdf/1-01.pdf).

2) P. M. Elias, Epidermal lipids, barrier function and desquamation. J. Invest. Dermatol., 80 (supple.), 44s-49s (1983).

3）赤堀四郎「生命（いのち）とは-思索の断章 -」共立 出版 (1988)

4）オパーリン（石本真訳）「生命一その本質, 起源, 発展 一」岩波書店（1965）。

5）上田岳彦, 砂本順三, 「生体膜の構造」, 化学と生物, 33, 808-813 (1995) 
Table 2 経皮吸収に関する総説の目次 ${ }^{41)}$

\begin{tabular}{|l|l|}
\hline Skin Penetration & \\
\hline Introduction & \\
\hline A little bit about Histry & \\
\hline Skin Structure/Properties & \\
\hline Factors Affecting the Skin Barrier & \\
\hline Assesing the Skin Barrier & \\
\hline Overcoming the Skin Barrier & \\
\hline Skin Penetration & \\
\hline Evaluation fo Skin Penetration & In vitro/Ex vivo Studies \\
\hline & Membranes \\
\hline & In vivo Studies \\
\hline & In vivo Imaging \\
\hline & In vivo Tape Stripping \\
\hline & In vivo Skin Blanching/Vasoconstrictor Assey \\
\hline & In vivo Microdialysis \\
\hline & In Silico Models \\
\hline & \\
\hline Future Directions & 139 referencs \\
\hline References & \\
\hline
\end{tabular}

6) K. Sakamoto, The Inportance of Planarity for Lipid Bilayer as Biomembranes. Advances in Biomembranes and Lipid Self-Assembly, 23, 1-23 (2016).

7) Y. Uchida, Skin Lipids. in COSMETIC SCIENCE AND TECHNOLOGY: THEORETICAL PRINCIPLES AND APPLICATIONS. Elsevier, pp. 685-698 (2017)

8) L. Norlen, Skin Barrier Formatiopn: The Membrane Folding Model. J. Invest. Dermatol., 117, 823-829 (2001).

9) T. Iwata, Lamellar Gel Network. in COSMETIC SCIENCE AND TECHNOLOGY: THEORETICAL PRINCIPLES AND APPLICATIONS. Elsevier, pp. 415-447（2017）。（ラメラゲルは水和した両親媒性物質 2 分子膜が層状に累積した構造を持ち，その疎水基の 炭化水素鎖はトランスジグザグに充填したへキサゴナ ル構造のパッキング構造を持つ準安定な $\alpha$ 結晶状態に ある。これは，半固形製剂と称される処方の骨格をな す $\alpha$ ゲルと呼ばれる構造体と類似のものである)

10) J. A. Bouwstra, G. S. Cooris, J. A. van der Spek, W. Bras, Structual investigation of human stratum corneum by small angle X-ray scattering. J. Invest. Dermatol., 97, 1005-1012 (1991).

11) J. A. Bouwstra, G. S. Cooris, W. Bras, D. T. Downing, Lipid organization in pig stratum corneum. J. Lipid Res.. 36, 685-695 (1995).

12) J. A. Bouwstra, P. L. Honeywell-Nguyen, G. S. Goories, M. Ponec, Structure of the skin barrier and its modulation by vesicular formulations. Prog. Lipid Res., 42, 1-36 (2003).

13) I. Hatta, N. Ohta, Photon Factory Activity Report 2003
Part A, Hilights, pp. 49-50 (2004).

14）八田一郎, 皮膚のバイオサイエンス一皮膚角層の構造 と機能一，日本接着学会誌，52，145-151 (2016).

15) I. Hatta, Structural Aspects of Stratum Corneum. in COSMETIC SCIENCE AND TECHNOLOGY: THEORETICAL PRINCIPLES AND APPLICATIONS. Elsevier, pp. 699-709 (2017).

16) S. H. White, D. Mirejovsky, G. I. King, Structure of lamellarlipid domains and corneocyte envelops of murine stratum corneum. An X-ray diffraction study. Biochemistry 27, 3725-3732 (1988).

17) J. A. Baouwstra, G. S. Cooris,, M. Ponec, The lipid organization of the skin barrier: liquid and crystalline domains coexist in lamellarphases. J. Biol. Phsic. 28, 211-223 (2002).

18) I. Hatta, N. Ohta, K. Inoue, N. Yagi, Coexsitence of two domains in intercellular lipid matrix of stratum corneum. Biochem. Biophys. Acta, 1758, 1830-1836 (2006).

19) D. Groen, D. S. Poole, G. S. Gooris, J. A. Bouwstra, Is an orthorhombic lateral packing and a proper lamellar organization important for the skin barrier function? Biochim. Biophys. Acta, 1808, 1529-1537 (2011).

20) M. Q. Man, Y. Hatano Y, S. H. Lee, M. Man, S. Chang, K. R. Feingold, D. Y. Leung, W. Holleran, Y. Uchida, P, Elias, Characterization of a hapten-induced, murine model with multiple features of atopic dermatitis: structural, immunologic, and biochemical changes following single versus multiple oxazolone challenges, $J$. Invest. Dermatol., 128, 79-86 (2008).

21) K. Abrai, S. Yoshino, K. Sakai, H. Sakai, M. Abe, N. Loiseau, W. Holleran, Y. Uchida, K. Sakamoto, Physico- 
chemical analysis of liposome membranes consisting of model lipids in the stratum corneum. J. Oleo Sci., 60, 197-202 (2011).

22) N. Loiseau, Y. Obata, S. Moradian, H. Sano, S, Yoshino, K. Aburai, K. Takayama, K. Sakamoto, W. M. Holleran, P. M. Elias, Y. Uchida, Altered sphingoid base profiles predict compromised membrane structure and permeability in atopic dermatitis. J. Dermatol. Sci., 72, 296303 (2013).

23）川崎由明, 全丹毅, 坂本一民, 電子スピン共鳴（ESR） によるアニオン界面活性剤の角質層におよぼす影響の 解析, 日本化粧品技術者会誌 (J. Soc. Cosmet. Chem. Jpn.)，29，252-257 (1995).

24）川崎由明，坂本一民 H. I. Maibach，電子スピン共鳴 (ESR) によるアニオン界面活性荗の角質層におよぼす 影響の解析, 日本化粧品技術者会誌 (J. Soc. Cosmet. Chem.Jpn.), 30, 55-61 (1996).

25) Y. Kawasaki, D. Quan, K. Sakamoto, H. I. Maibach, Electron Resonance Study on the Influence of Anionic Surfactants on Human Skin. Dermatology, 194, 238-242 (1997).

26) J. Mizushima, Y. Kawasaki, K. Sakamoto, M. Kawashima, R. Cooke, H. I. Maibach, Electron paramagnetic resonance study utilizing stripping method on normal human stratum corneum. Int. J. Pharmaceutics, 197, 193-202 (2000).

27) E. Yagi, K. Sakamoto, K. Nakagawa, Depth dependence of stratum corneum lipid ordering: a slow-tumbling simulation for electron paramagnetic resonance. J. Invest. Dermatol., 127, 895-899 (2007).

28) R. R. Warner, M. C. Myers, D. A. Taylor, Electron probe analysis of human skin: determination of the water concentration profile. J. Invest. Dermatol., 90, 218-224 (1988).

29) I. Horii, Y. Nakayama, M. Obata, H. Tagami, Stratum corneum hydration and amino acid content in xerotic skin. Br. J. Dermatol., 121, 587-592 (1989).

30) D. Bommann, R. O. Potts, R. H. Guy, Examination of stratum corneum barrier function in vivo by infrared spectroscopy. J. Invest. Dermatol., 95, 403-409 (1990).

31) F. Bonte, A. Saunois, P. Pinuet, A. Meybeck, Existence of a lipid gradient in the upper stratum corneum and its possible biological significance. Arch. Dermatol.
Res., 289, 78-82 (1997)

32) P. J. Caspers, G. W. Lucassen, E. A. Carter, H. A. Bruning, G. J. Puppels, In vivo confocal Raman microscopy of the skin: noninvasive determinationof molecular concentration profiles. J. Invest Dermatol., 116, 434-442 (2001).

33) A. Weerheim, M. Ponac, Determination of stratum corneum lipid profile by tape stripping in combination with high-performanve thin-layer chromatography. Arch. Dermatol. Res., 293, 191-199 (2001).

34) J. A. Bouwstra, A. De Graff, G. S. Gooris, J. Nijsee, J. W. Wiechers, A. C. van Aelst, Water distribution and related morphology in human stratum corneum at different hydration levels. J. Invest Dermatol., 120, 750-758 (2003).

35）芋川玄爾，皮膚角質細胞間脂質の構造と機能．油化学， 44, 751-766 (1995).

36）田上八朗，皮膚の医学：肌荒れからアトピー性皮膚炎 まで，中公新書 1467，pp. 43 (1999)。（本文から一部 引用「人間の皮膚は…長い事水中で生活するようには できていません。かつてべトナム戦争の最中にアメリ カ兵を悩ませたのは $\cdots$ 水でした。‥当時のアメリカの 皮膚科医は, この「水漬けの足」と呼ばれる変化をど う防ぐかを真剣に研究していました。」

37）川崎由明, 坂本一民, H. I. Maibach, In vitroによるア ミノ酸のヒト皮膚での経皮吸収挙動の解析. 日本化粧 品技術者会誌 (J.SCCJ)，30，55-61（1996）。

38）井形幸代, 川崎由明, 坂本一民, 湿潤剤の差別化：吸 湿性試験を用いた方法, 日本化粧品技術者会誌 $(J$. SCCJ), 27, 450-458 (1993).

39) K. Sakamoto, Development of two new moisturizing ingredients. Cosmet. Toiletries, 99, 109-110, 112-114, 116-117 (1984).

40) J. A. Bouwstra, G. S. Gooris, F. E. R. Dubbelaar, M. Ponec, Phase behavior of lipid mixtures based on human ceramides: coexistence of crystalline and liquid phases. J. Lipid Res., 42, 1759-1770 (2001).

41) A. C. H. R. Machado, P. S. Lopes, C. P. Raffier, I. N. Haridass, M. Roberts, J. Grice, V. R. Leite-Silva, Skin Penetration. in COSMETIC SCIENCE AND TECHNOLOGY: THEORETICAL PRINCIPLES AND APPLICATIONS, Elsevier, pp. 741-755 (2017). 